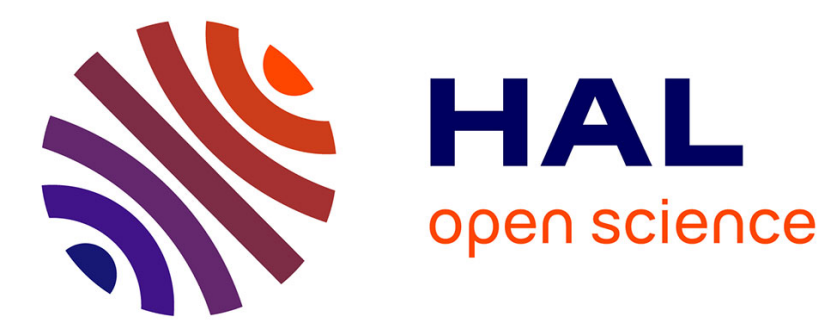

\title{
Characteristics of Human Resources Management In Tourism Industry of Republic of Armenia \\ Koryun Atoyan
}

\section{To cite this version:}

Koryun Atoyan. Characteristics of Human Resources Management In Tourism Industry of Republic of Armenia. International Conference on Business, Marketing and Information System Management, Nov 2015, Paris, France. 10.15242/ICEHM.ED1115001 . hal-03283529

\section{HAL Id: hal-03283529 \\ https://hal.science/hal-03283529}

Submitted on 10 Jul 2021

HAL is a multi-disciplinary open access archive for the deposit and dissemination of scientific research documents, whether they are published or not. The documents may come from teaching and research institutions in France or abroad, or from public or private research centers.
L'archive ouverte pluridisciplinaire HAL, est destinée au dépôt et à la diffusion de documents scientifiques de niveau recherche, publiés ou non, émanant des établissements d'enseignement et de recherche français ou étrangers, des laboratoires publics ou privés. 


\title{
Characteristics of Human Resources Management in Tourism Industry of Republic of Armenia
}

\author{
Koryun Atoyan
}

\begin{abstract}
Human Resources are the most important assets for any kind of institutions. The tourism and hospitality industry is considered one of the most sectors that rely on the human element in the provision of services, the critical importance of employees' involvement in the quality process of an organization is based on belief that the best process innovation ideas come from people actually doing the job (Bank 1992; thiagarajan \& Zairi 1997). Tourism industry specially hotel industry undoubtedly a labor intensive industry. Its success depends "on the social and technical skills of its personnel, their ingenuity and hard work, their commitment and attitude" Gabriel, 1988; anastassova and Purcell, 1995; Mohinder \& katu 2007) [1].

It is also true in the labor intensive industry; the effective utilization of human resource can give an organization its competitive edge (Schneider \&Bowen, 1993; Mohinder, 2004). "BY effectively linking with HRM with organizational objectives and needs, human resources can be recruited, developed, motivated and retained towards gaining a competitive advantage" (Chenge and Brown, 1998; Mohinder \& Katou 2007).

Thus the success of the tourism and hospitality industry depends on the quality of its employees and their effective management in order to assist the organization to achieve its objective. this research prepared to study the human management resources environment in Armenia and analyses the situation of this management, and its efficiency, and its needs.
\end{abstract}

Keywords - Tourism, Human Resources Management, Personnel Management, Tourism And Hospitality Industry, Training.

\section{INTRODUCTION}

$\mathrm{T}$ O identify the features of human resources management in the Republic of Armenia have been prepared a questionnaire to collect information and make an assessment on the mechanism of action and effectiveness of human resources management in tourism enterprises.

The survey of the human resources management in the tourism sector was conducted based on a questionnaire and was completed through personal interviews.

The interviews with HR managers and the representatives of selected tour operators and travel agencies, hotels, restaurants were conducted between May 1-20, 2015 and lasted between 45 minutes to 1 hour.

Detailed interviews were conducted with 20 entities, 10

Koryun Atoyan Professor, Rector of University, Doctor of Sciences, Armenian State University of Economics, Yerevan, Armenia hotels, 6 tour agencies, and 4 restaurants and complemented with analysis of the current situation in the Armenian tourism sector from other research and survey findings.

(Only locally owned establishments were included in the sample).

\section{II.SURVEY RESULTS}

Results of the survey were analyzed using the SPSS statistical software and MS Excel. The survey revealed that the structure of the human resources management functions performed by the companies is not effective. The functions of job analysis and development of job descriptions, implementation of human resources policy, procedures and systems, and performance appraisal are not accomplished by the majority of companies, or it is common functions between HR manager and another managers.

Analyze of Main Directions of Personnel Management in Tourism Organizations of Armenia

The results showed that the share of employees at the hotels and restaurants made up more than $90 \%$ of the total number of the employed at the observed companies.

Q1: How many people are working at your company (registered and unregistered). including part-time staff:

TABLE I

NUMBER OF WORKERS

\begin{tabular}{|l|c|c|}
\hline including part-time staff: & Frequency & $\%$ \\
\hline More than 75 & 10 & 50 \\
\hline $40-75$ & 3 & 15 \\
\hline $10-39$ & 5 & 25 \\
\hline Fewer than 10 & 8 & 40 \\
\hline Total & 20 & 100 \\
\hline
\end{tabular}

Q2: Please indicate the gender profile of your staff (number of male and female staff in the total number of staff):

TABLE II

GENDER PROFILE

\begin{tabular}{|l|c|c|}
\hline & Number & $\%$ \\
\hline $\begin{array}{l}\text { At least two thirds } \\
\text { female }\end{array}$ & 8 & 40 \\
\hline $\begin{array}{l}\text { Between a half and a } \\
\text { third female }\end{array}$ & 8 & 40 \\
\hline Less than half female & 4 & 20 \\
\hline
\end{tabular}

The human resources functions

Q5: What functions are performed by Human Resources Department? 
The human resources functions at the hotels are performed by the Executive Director, and Human Resources manager. At the small companies the HR functions are performed mainly by the Executive Director.

TABLE III

HUMAN RESOURCES FUNCTIONS

\begin{tabular}{|l|l|l|l|}
\hline$\%$ & Frequency & Function & \\
\hline 3.278689 & 2 & Job analysis & 1 \\
\hline 16.39344 & 10 & Development of HR policy & 2 \\
\hline 24.59016 & 15 & Recruitment and selection of employees & 3 \\
\hline 13.11475 & 8 & Performance appraisal & 4 \\
\hline 13.11475 & 8 & training/educational programs & 5 \\
\hline 9.836066 & 6 & rewarding & 6 \\
\hline 19.67213 & 12 & labor relation & 7 \\
\hline 100 & 61 & Total & \\
\hline
\end{tabular}

And the analysis showed the percentage:

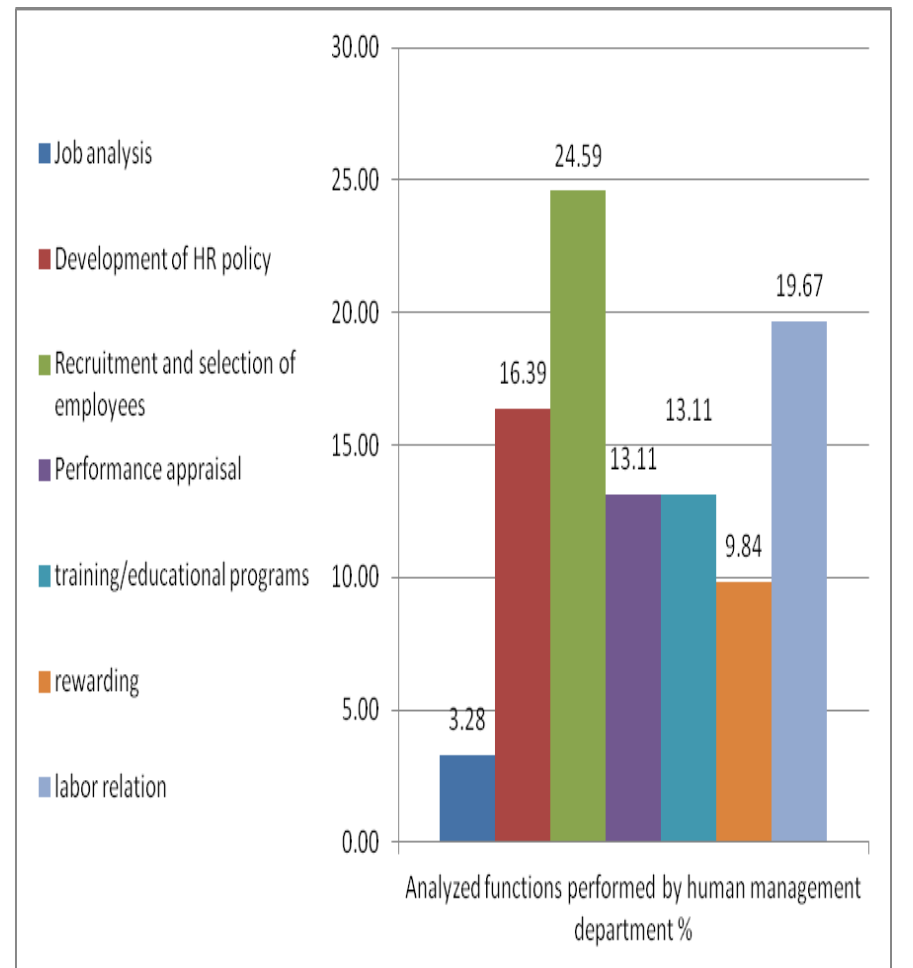

Fig 1. Analyzed Functions Performed By Human Management Department

Generally recruiting and selecting people to fill new or existing positions are a crucial element of human resource activity in all tourism and hospitality organizations, irrespective of size, structure or activity. Although we have noted how the importance of service quality has increased the pressure on organizations to select the 'right' kind of individual, (figure number 1) Showed that the recruitment and selection of employees the most important function among $\mathrm{HR}$ function $25 \%$, and training $20 \%$.while the performance appraisal $13 \%$.and the labor relation only $3 \%$.

Job Analysis and job description
Q6: Does each of your employees have written description of their responsibilities, or job descriptions?

Q7: Do you analyze jobs before designing job description?

Job Analysis: is a systematic exploration of the activities within a job.

It defines and documents the duties, responsibilities and accountabilities of a job and the conditions under which a job is performed.

Job Descriptions: Written statement of what jobholder does, how it is done, under what conditions and why. Used to describe the job to applicants, to guide new employees, and to evaluate employees.

TABLE IV

WRITTEN STATEMENT OF WHAT JOBHOLDER DOES

\begin{tabular}{|l|c|c|}
\hline & Frequency & Percent \\
\hline 0. NO & 7 & 35 \\
\hline 1. YES & 13 & 65 \\
\hline TOTAL & 20 & 100 \\
\hline
\end{tabular}

TABLE $\mathrm{V}$

JOB DESCRIPTION

\begin{tabular}{|l|c|c|}
\hline & FREQUENCY & PERCENT \\
\hline YES & 1 & $5 \%$ \\
\hline NO & 6 & $30 \%$ \\
\hline $\begin{array}{l}\text { We use job descriptions } \\
\text { from employees } \\
\text { Qualifications directory }\end{array}$ & 13 & $65 \%$ \\
\hline Total & & \\
\hline
\end{tabular}

Around $35 \%$ of respondents report that their company does not have written descriptions of their responsibilities, or job descriptions. Only one company reported on job analysis before designing job description. The overwhelming majority of respondents $(65 \%)$ that they use job descriptions from the existing Employees Qualification directory.

\section{Recruitment and Selection of Employees:}

Recruitment is defined by Heery and Noon (2001: 298) as 'the process of generating a pool of candidates from which to select the appropriate person to fill a job vacancy'.

Recruitment is a dynamic process as within organizations people are constantly retiring, resigning, being promoted or, at times, being dismissed. Most HR managers during the interviews said (particularly the large hotels) they use formal methods such as employment and career centers, and use databases of resume, recommendations, word of mouth, as well as publish or follow the announcements in newspapers, journals and Internet. 
TABLE VI

METHODS FOE SELECT EMPLOYEE

\begin{tabular}{|c|c|c|c|}
\hline & Type & frequency & $\%$ \\
\hline 1 & Apply to colleagues or other employers & 12 & 18.46154 \\
\hline 2 & Apply to relatives and acquaintances & 2 & 3.076923 \\
\hline 3 & $\begin{array}{l}\text { Publish or follow the announcements } \\
\text { (newspapers, journals, Internet and } \\
\text { others) }\end{array}$ & 12 & 18.46154 \\
\hline 4 & Partner universities/institutions & 8 & 12.30769 \\
\hline 5 & $\begin{array}{l}\text { Non-partner higher educational/training } \\
\text { institutions }\end{array}$ & 3 & 4.615385 \\
\hline 6 & $\begin{array}{l}\text { Word of Mouth (recommendations, } \\
\text { resume) }\end{array}$ & 12 & 18.46154 \\
\hline 7 & Employment and career centers & 15 & 23.07692 \\
\hline 8 & Other (specify) & 0 & 0 \\
\hline & Total & 67 & 100 \\
\hline
\end{tabular}

Q20 Do $\mathrm{u}$ have an appraisal system for the evaluation of employee performance?

Q21 If yes, what methodologies of appraisal of employees performance are used?

Performance appraisal is defined by Heery, and Noon (2001: 7) as,' the process of evaluating the performance and assessing the development/training needs of an employee'. Performance appraisal can arguably be seen to again reflect to some degree the notions of 'hard' and 'soft' HRM. IDS (1989, cited in McKenna and Beech, 2002) suggest a number of performance factors which are likely to be appraised, the most important being:

- Knowledge, ability and skill on the job.

- Attitude to work expressed as enthusiasm, commitment and motivation.

- Quality of work on a consistent basis and attention to detail.

- Volume of productive output.

- Interaction, as exemplified in communication skills and ability to relate to others in teams.

Woods et al. (1998) found that hotels in their survey used one or more of four approaches, these being management by objective (MBO) (48 per cent), behaviorally anchored rating scales (BARS) (41 per cent), and narrative essay (37 per cent) and graphic rating scale (28 per cent).

Other methods which organizations may use include performance standards and, matching performance against job descriptions, rating an employee based on a scale, which may for example range from 'outstanding' to 'unacceptable' and critical incidents.

The survey showed that the appraisal system for the evaluation of employee performance is not available at nearly $80 \%$ of companies. In hotels they use alternation ranking method (ranking of the employees with best and worst performance). And all companies reported that the supervisors monitor the performance of workers directly and sends a report by the supervisor to the manager hr manager executive manager.
Payment Rewarding/Incentive Systems:

Q22 WHAT PAYMENT SYSTEM ARE USED?

Q23 Do you have pay increases linked to employee's performance?

Q24 what Rewarding/ Incentive Systems are used?

Concerning to the payment all companies use standard hour plan payment. And, for rewarding system most of the observed companies use the pay increases.

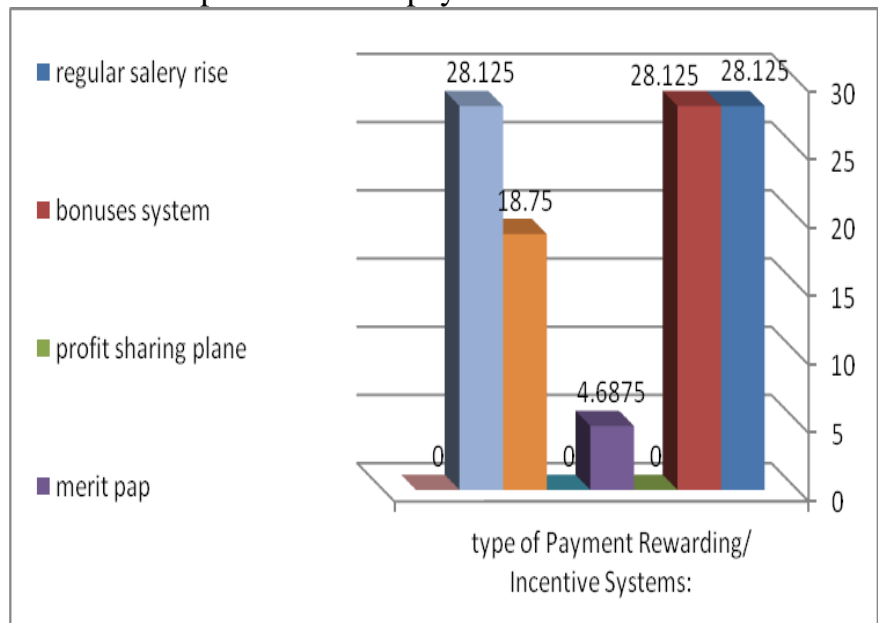

Fig. 2 Type of payment Rewarding/ Incentive Systems

The most popular types of rewarding systems are bonuses system and regular salary rise, compensation of personal (transportation, food) expenses In addition to the upgrade( in hotels).plus the non-financial rewards at work in all companies the direct relationship between the managers and the employees.

TABLE VII

TYPE OF PAYMENT REWARDING/INCENTIVE SYSTEM

\begin{tabular}{|r|l|c|l|}
\hline & \multicolumn{1}{|c|}{ Type of rewarding system } & frequenc & $\%$ \\
\hline 1 & Regular salary rise & 18 & 28.125 \\
\hline 2 & Bonuses system & 18 & 28.125 \\
\hline 3 & Profit sharing plan & 0 & 0 \\
\hline 4 & Merit pay & 3 & 4.6875 \\
\hline 5 & Stock points & 0 & 0 \\
\hline 6 & $\begin{array}{l}\text { Promotion and career development } \\
\text { opportunity }\end{array}$ & 12 & 18.75 \\
\hline 7 & $\begin{array}{l}\text { Compensation of } \\
\text { transportation, Food) expenses. }\end{array}$ & 18 & 28.125 \\
\hline 8 & Others (specify) & 0 & 0 \\
\hline & Total & 64 & 100 \\
\hline
\end{tabular}

Q25: Do you have short-term and long-term staff Training Programs?

Q26:If yes, what type of training program you have?

Q27: In which areas would $u$ need training for your employees?

One of the important functions of human resources management is development of short-term and long-term staff training programs. Analyzing training needs is a crucial part of HRD as the identification of needed skills and active management of employee learning is integral to developing 
corporate, and business strategies.

Training and development then can be seen as a key instrument in the implementation of HRM practices and policies and there may be a number of benefits from undertaking training. For example, McKenna and Beech (2002) suggest a number of benefits generally stemming from training, including:

- Helps employees learn jobs more quickly and effectively.

- Improves work performance of existing employees and keeps them up to date in specialist skills.

- Leads to a greater volume of work resulting from fewer mistakes and greater rapidity.

- Frees management time, less of which is spent rectifying errors, also reduces wastage.

- Can help to reduce turnover among new and established staff.

Incorporating safety training can help reduce accidents.

- Can help to attract good workers.

- Is a precondition for flexible working.

- Creates an attitude more receptive to coping with change.

((Some organizations who see training as an investment)).

The majority responded that they carry out regular staff training program $(75 \%)$ in house training. And the most needs for training skills were in hotels and restaurants (general skills) ; customer care skills, restaurant management skills and, product development skills.

For human management resources skills large hotels need: job analysis skills.

TABLE VIII

TYPE OF TRAINING PROGRAM

\begin{tabular}{|l|l|l|l|}
\hline & Type of training program & FREQUENCY & $\%$ \\
\hline A & In-house training including & & \\
\hline & Regular training courses & 20 & 71.42857 \\
\hline $2-$ & Mentoring, apprenticeship & 3 & 10.71429 \\
\hline B & Off-site training including & & \\
\hline 1 & Seminars, workshops & 2 & 7.142857 \\
\hline 2 & BSP training courses & 0 & \\
\hline 3 & College courses & 3 & 10.71429 \\
\hline C & Other (specify) & 0 & 0 \\
\hline & TOTAL & 28 & 100 \\
\hline
\end{tabular}

\section{CONCLUSION}

Armenia is ranked 71 st out of 141 countries in terms of quality of human resources, except if structure of human resource management functions currently performed by companies in tourism sector is not effective and needs improvement through the provision of the advisory services or trainings to enhance the ability of this administration to function independently [2].

Job analysis as the important prerequisite for the elaboration of job descriptions is not practiced at the observed companies. At the same time, performance appraisal practice is very limited and done roughly, mainly based on qualitative indicators. From this point the foreign experience on the peculiarities of job analysis and performance appraisal in tourism sector can be useful for the companies [3].

The submission of the advisory services or organization of training courses on labor legislation, labor code, its specifics for the services sector and private companies along with the observation of the international experience on labor legislation can be very helpful for the tourism companies.

Development of cluster relationships between the companies and educational establishments specialized in tourism field needs to be one of the most important directions of tourism development in the country.

The survey results showed that the highest training needs of respondents are concentrated on HRM general skills, job analysis skills and the absence of job analysis from HR functions reflect the importance of training courses for human management managers in this field.

On general skills side the highest training needs are registered on entrepreneurial and marketing, customer care skills, as well as on restaurant management/operation skills [4].

Encourage the internal tourism by give low praises for the local Armenians this enhance the internal tourism.

\section{REFERENCES}

[1] Gabriel Escarrer Julia. Chairman and Founder of Mela International Hotels. http://www.meliahotelsinternational.com/sites/default/files/consejoadministracion-cvs/GEJulia_en.pdf

[2] http://www.tourismarmenia.org/\#axzz3gEeu0bcL

[3] Dennis Nickson. Human Resource Management for the Hospitality and Tourism Industries. Publisher's Note: Transferred to Taylor \& Francis as of 2011

[4] Tourism and Hospitality Marketing: Bryan Simpson, Daniela Richmond. Sweden. 2014. 